\title{
A Clinical Study on the therapeutic effect of Katu taila Pichu in Pureeshaja Krimi W.S.R to Enterobius vermicularis infestation
}

\author{
Research Article
}

\author{
Krishna Santoshi $\mathbf{M}^{1^{*}}$, Krishnaiah $\mathbf{N}^{2}$ \\ 1. P.G. Scholar, S. V. Ayurvedic Medical College, Tirupati. \\ 2. Professor, P.G. Department of Kaumarabhritya, S. V. Ayurvedic Medical College, Tirupati.
}

\begin{abstract}
There are various factors that interfere growth $\&$ development of a child. The effects of several diseases that occur exclusively in childhood period may or may not be irreversible and interfere with Growth \& Development. The worm infestations have been responsible for worsening the living conditions in millions of children around the world affecting the growth and development, despite of remarkable progress in medical science. Worms seem to be affecting the human beings right from the Vedic as there are references of the same. Hence the present study was intended to evaluate the therapeutic efficacy of the selected drug in management of Enterobiasis, to find out economical therapy for Krimi roga with minimum or no side effect and to prevent further complication. 30 Patients suffering from Krimi roga (infested with pinworm) based on the clinical symptoms and fulfilling the inclusion criteria were selected from the OPD and IPD, of S.V.Ayurvedic hospital in bala roga unit. The patients were selected randomly into two groups each comprising of 15 patients. Group A (Control) were given swab of distilled water and Group B (Trial) - were given swab of tepid Katu tailam with saindhava lavana. The case particulars were drafted in specially designed case sheet. Response to the treatment was assessed with the help of detailed case sheet proforma that was specifically designed for the study. The subjective and objective parameters were graded into different categories basing on their condition using a 4 point grading scale. The results were evaluated. The data was collected and analysed to compare the effect of the treatment before and after treatment between control and trial groups using unpaired t-test. The selected drug proved efficacious in controlling the Enterobiasis by interrupting the autoinfection cycle and reducing the reservoir of infection.
\end{abstract}

Keywords: Krimi, Pin worms, Thread worms, Enterobiasis, Enterobious vermicularis, Katu Taila Pichu.

\section{Introduction}

Since the Vedic period, Krimi are one of the oldest companions of the human beings. Ancient acharyas were well aware regarding the manifestation of the microorganisms. There are some indirect references in Vedas for microbes and infectious diseases in the name of Krimi \& Krimi Rogas. Krimi are thought to be the causative factors of a number of diseases. Krimi enter into body and produce number of diseases (1).

The vital stage of growth \& development is childhood; hence the need for protection of childhood from infections, infestations, and diseases has to be an utmost priority. Poor scholastic performance, frequent use of antibiotics unexplained nervous excitement and weight loss even after providing adequate nutrition to

\footnotetext{
*Corresponding Author:

Krishna Santoshi M,

PG Scholar,

Department of Kaumarabhritya,

SV Ayurvedic Medical College, Tirupati

Andhra Pradesh, India

Email id: mkrishnasantoshi@gmail.com
}

the child should be suspected of Krimi.

Most pediatric population gets affected with pin worms, which resemble small thread like pieces, like rice grains and cause itching in the perianal region. Present study on Pinworms is taken up, which generally develops as a result of unhygienic personal habits like finger sucking, improper maintenance of nails, intake of worm-infested food and water.

Pinworms are particularly common in preschool \& Kindergarten children, with prevalence rates in this age group having been reported as high as $61 \%$ in India, 50\% in England, 39\% in Thailand, 37\% in Sweden, and 29\% in Denmark (2). Because it spreads from host to host through contamination, pinworms are common amid people living in close contact. The occurrence of pinworms is not associated with gender nor with any particular social class, race, or culture. Pinworms are an exception to the principle that intestinal parasites are uncommon in affluent communities. The highest incidence is seen in congested urban areas, institution or in large family. The infection brought by a child may spread to other children and tends to occur in all people within a household.

Pinworms infect only humans and reside in the 
intestines. Children living in closed communities like Toddlers (day care centers) to School going kids encounter this problem as they are easily spread even through air (carrying ova). Auto \& retro infections were noted even after deworming as per statistics. In a long stand, untreated kids may face weakness, anemia, loss of appetite etc.

Despite robust advances in the field of microbiology, challenges sustain. Hence, an effort has been made to compile the management strategies of Ayurveda to find solutions for the above challenges.

\section{Aims and Objectives}

To evaluate the efficacy of guda pichu (Katu taila and Saindhava lavana) in Enterobiasis.

To find out economical therapy for Krimi roga with minimum or no side effect and to prevent complication. To study ancient and modern literature of Krimi in detail.

\section{Materials and Methods}

The present study is a simple randomised controlled therapeutic clinical trial.

\section{Method of collection of the data Study design}

The present study is a simple randomised controlled clinical trials.

\section{Sample}

30 Patients suffering from Krimi roga (infested with pinworm) based on the clinical symptoms and fulfilling the inclusion criteria were selected from the OPD and IPD, of S.V.Ayurvedic hospital in bala roga unit.

\section{Diagnostic criteria}

Diagnosis was made on the basis of signs \& symptoms, and history. Complete history and clinical evaluation of all patients were assessed by both Ayurveda and modern methods of clinical examination and recorded in a specially designed proforma.

\section{Subjective parameters}

Children with guda kandu (Peri anal itching) in association with two or more general features of Krimi like Udara shoola (Pain Abdomen), Anidra (Sleeplessness), Agni mandya (Lack of appetite), Vaivarnya (discolouration), and Pratisyaya (cough and cold).

\section{Objective parameters}

- Inspection and

- Microscopic stool examination and scotch tape test, positive to ova, worm of pinworm.

Criteria for selection of the patients:

Inclusion criteria:

1. Children below 16yrs
2. Patients suffering from Pureeshaja Krimi (Pinworm infestation- Enterobius vermicularis)

\section{Exclusion criteria}

1. Patient suffering from other than pinworm infestations.

2. Patients aged above 16 years

3. Patients undergoing any other treatment

4. Patients with severe malnourishment

The patients are selected randomly into two groups each comprising of $\mathbf{1 5}$ patients.

- Group A (Control) - 15 Patients would be given swab of Udakam (distilled water) that is slightly inserted into the anus.

- Group B (Trial) - 15 patients would be given swab of tepid Katu tailam with saindhava lavana that is slightly inserted into the anus.

\section{Materials used for the study}

- Katu Taila-Procured from local market

- Saindava lavana-Procured from local market

- Pichu-Gauze piece (swab)

- Udakam-Distilled water- Procured from local medical store

\section{Procedure of administration of Pichu}

A swab soaked in Luke warm mustard oil added with little saindhava lavana is slightly inserted into the anus overnight. 2 gm of Saindhava lavana was mixed in $30 \mathrm{ml}$ of Katu taila and dispensed to the patient in a transparent, sterile plastic container. Pichu was immersed in the above preparation and used. (3)

\section{Observation and data collection:}

- Group A-Control group was observed and evaluated before treatment and at the end of nine weeks ( $63^{\text {rd }}$ day) of treatment.

- Group B- Trial group was observed and evaluated before treatment and at the end of nine weeks ( $63^{\text {rd }}$ day) of treatment.

\section{Assessment criteria}

Response to the treatment was assessed with the help of detailed case sheet proforma that was particularly prepared for the study. The subjective and objective parameters were graded into different categories basing on their condition using a 4 point grading scale and the findings were recorded before and after treatment on $21^{\text {st }}$ day, 42nd day and 63rd day. The results were evaluated.

The parameters were:

- Gudakandu (Perianal itching)

- Anidra (Sleeplessness)

- Agnimandya (Loss of apetite)

- Udarasoola (Pain abdomen)

- Pratisyaya (Cold and cough)

- Vivarnya or Vivarnata (Discolouration) 


\section{Gradation of assessment criteria}

\section{Gudakandu (Perianal itching) :}

0 - Absent

1 - Itching present at few (1 or 2) times in a day

2 - Itching present for many times in a day

3 - Continuous itching- Itching at very frequent intervals

\section{Anidra (sleeplessness) :}

0 - Sound sleep

1 - Waking up intermittently without disturbing sleep

2 - Waking up frequently with disturbing sleep

3 - Unable to sleep continuously or very insufficient sleep

Agnimandya (sleeplessness) :

0 - Good or Normal appetite

1 - Eating regularly but decreased quantity

2 - Irregular eating due to low appetite and decreased quantity

3 - Skipping of meal frequently and takes minimal quantity.

\section{Udarasoola (Pain abdomen) :}

0 - Absent

1 - Mild pain

2 - Moderate pain-Pain with grimace

3 - Severe pain-Pain with tenderness

Pratisyaya (Cold and cough)

0 - Absent

1 - Stuffiness of nose or blocked nose

2 - Stuffiness of nose and discomfort in throat

3 - Sneezing (Cold), cough, dyspnea

Vaivarnya or vivarnata (Discolouration)

0 - Absent (Normal skin)

1 - Dry and pale face

2 - Dry, Pale with marked local discolourations

3 - Dryness, Puffiness and paleness with extensive discolouration or distinct patches

Presence of ova/worm in microscopic stool examination

0 - Absent

1 - Present

Presence of ova/worm in Scotch tape test

0 - Absent

1 - Present

Method: Scraping from the perianal skin by a cellophane sticking plaster.

\section{Laboratory investigations}

Microscopic stool examination

Scotch tape test

\section{Follow up:}

At the end of $10^{\text {th }}, 12^{\text {th }}$ week after treatment patients of both the groups were observed, examined, and assessed for the signs and symptoms.

\section{Stool sample}

Was evaluated before and after treatment

\section{Scotch tape test}

Was evaluated before and after treatment

\section{Statistical analysis}

The data collected pertaining to the assessment criteria was analysed to compare the effect of the treatment before and after treatment between control and trial groups using unpaired t-test.

\section{Discussion on the diet habits}

Irregular diet (Ajirna Bhojana) is one of the etiological factors affecting the samprapti of krimi roga. Irregular diet habits leading to mandagni thus resulting in Ama formation. Out of the 30 patients taken for study, $27 \%$ were with regular diet habit and $73 \%$ patients with irregular diet habit.

\section{Mode of onset of disease}

Majority of the patients had gradual onset of disease $73 \%$ where as $27 \%$ patient were with acute onset of disease. This may be because the clinical features are not very severe in onset and disease. The life span of the worms is relatively brief, long standing infections are due to continuous reinfection. (Source: 118- Principles and practices of infections)

\section{Signs and symptoms wise distribution}

In the present study the prevalence of the symptoms in the subjects was Gudakandu $100 \%$, Vibandham 100\%, Agnimandya 93\%, udara Soola $90 \%$, pratisyaya $87 \%$, vivarnya $60 \%$ and Krisatva in $53 \%$ of the patients. These are the most common and major diagnostic features of Krimi roga. This also acknowledges samprapti of Krimi roga narrated in Ayurveda treatises. In severe types of worm infestations there might be discoloration of skin (Vaivarnya), and skin becomes dry and muddy in colour.

\section{Results and Discussion}

The results of the study are as per the Table No. 1.

\section{Effect on Gudakandu}

Of the total 30 patients in the study all the patients were found to be suffering from Gudakandu (100\%). Reduction of about $97 \%$ respectively, were also extremely statistically significant ( $<<0.001)$. Where as in Group A the reduction in guda kandu was $29 \%$ reduction at the end of $9^{\text {th }}$ week, and was not statistically significant $(p>0.001)$.

Perianal itching is due to the eggs $(11,000$ to 16000) deposited in the patient. Present study indicates that the Katu taila pichu in the perianal region is highly effective in destroying the eggs and worms if any thus reducing perianal itching. 
International Journal of Ayurvedic Medicine, 2019, 10(1), 82-88

Table No. 1: Showing the results of the subjective and objective paramaters of the study.

\begin{tabular}{|c|c|c|c|c|c|c|c|c|c|c|c|c|}
\hline & \multirow[t]{2}{*}{ Group } & \multicolumn{2}{|c|}{ MEAN } & \multicolumn{2}{|l|}{ SD } & \multicolumn{2}{|c|}{ SEM } & \multirow[t]{2}{*}{$\overline{\text { Df }}$} & \multirow[t]{2}{*}{ t-value } & \multirow[t]{2}{*}{ p-value } & \multirow{2}{*}{$\begin{array}{l}\% \text { of } \\
\text { benefit }\end{array}$} & \multirow[t]{2}{*}{ Significance } \\
\hline & & BT & AT & BT & $\overline{A T}$ & $\overline{\text { BT }}$ & $\overline{\mathrm{AT}}$ & & & & & \\
\hline \multirow[t]{2}{*}{ Gudakandu } & $\overline{\mathbf{A}}$ & 2.33 & 1.80 & 0.72 & 0.86 & 0.19 & 0.22 & 28 & 1.8353 & 0.0771 & 29 & $\begin{array}{l}\text { Not quite } \\
\text { statistically } \\
\text { significant }\end{array}$ \\
\hline & $\overline{\text { B }}$ & 2.40 & 0.07 & 0.63 & 0.26 & 0.16 & 0.07 & 28 & 13.2288 & 0.0001 & 97 & $\begin{array}{l}\text { Extremely } \\
\text { statistically } \\
\text { significant }\end{array}$ \\
\hline \multirow[t]{2}{*}{ Anidra } & $\bar{A}$ & 1.27 & 1.07 & 0.96 & 0.88 & 0.25 & 0.23 & 28 & 0.5933 & 0.5578 & 16 & $\begin{array}{l}\text { Not quite } \\
\text { statistically } \\
\text { significant }\end{array}$ \\
\hline & $\bar{B}$ & 1.67 & 0.00 & 0.98 & 0.00 & 0.25 & 0.00 & 28 & 6.6144 & 0.0001 & 100 & $\begin{array}{l}\text { Extremely } \\
\text { statistically } \\
\text { significant }\end{array}$ \\
\hline \multirow[t]{2}{*}{ Agnimandya } & $\bar{A}$ & 2.00 & 1.60 & 0.76 & 0.91 & 0.20 & 0.24 & 28 & 1.3093 & 0.2011 & 20 & $\begin{array}{l}\text { Not quite } \\
\text { statistically } \\
\text { significant. }\end{array}$ \\
\hline & $\bar{B}$ & 2.33 & 0.53 & 0.72 & 0.64 & 0.19 & 0.17 & 28 & 7.2161 & 0.0001 & 77 & $\begin{array}{l}\text { Extremely } \\
\text { statistically } \\
\text { significant } \\
\end{array}$ \\
\hline \multirow[t]{2}{*}{ Vaivarnya } & $\overline{\mathbf{A}}$ & 1.33 & 1.07 & 1.40 & 1.03 & 0.36 & 0.27 & 28 & 0.5944 & 0.5570 & 20 & $\begin{array}{l}\text { Not quite } \\
\text { statistically } \\
\text { significant }\end{array}$ \\
\hline & B & 1.47 & 0.20 & 1.06 & 0.41 & 0.27 & 0.11 & 28 & 4.3106 & 0.0002 & 86 & $\begin{array}{l}\text { Extremely } \\
\text { statistically } \\
\text { significant }\end{array}$ \\
\hline \multirow[t]{2}{*}{ Udarasoola } & $\overline{\mathbf{A}}$ & 1.73 & 1.47 & 1.03 & 0.99 & 0.27 & 0.26 & 28 & 0.7218 & 0.4764 & 15 & $\begin{array}{l}\text { Not quite } \\
\text { statistically } \\
\text { significant }\end{array}$ \\
\hline & $\bar{B}$ & 1.67 & 0.00 & 0.98 & 0.00 & 0.25 & 0.00 & 28 & 10.5879 & 0.0001 & 100 & $\begin{array}{l}\text { Extremely } \\
\text { statistically } \\
\text { significant }\end{array}$ \\
\hline \multirow[t]{2}{*}{ Parushyam } & $\mathbf{A}$ & 1.40 & 0.93 & 0.74 & 0.59 & 0.19 & 0.15 & 28 & 1.9102 & 0.0664 & 33 & $\begin{array}{l}\text { Not quite } \\
\text { statistically } \\
\text { significant. }\end{array}$ \\
\hline & $\bar{B}$ & 1.33 & 0.60 & 0.98 & 0.74 & 0.25 & 0.19 & 28 & 2.3227 & 0.0277 & 55 & $\begin{array}{l}\text { Statistically } \\
\text { significant }\end{array}$ \\
\hline \multirow[t]{2}{*}{ Pratisyaya } & $\mathbf{A}$ & 1.60 & 1.00 & 1.24 & 1.07 & 0.32 & 0.28 & 28 & 1.4180 & 0.1672 & 37 & $\begin{array}{l}\text { Not quite } \\
\text { statistically } \\
\text { significant. }\end{array}$ \\
\hline & B & 1.80 & 0.13 & 0.94 & 0.35 & 0.24 & 0.09 & 28 & 6.4245 & 0.0001 & 93 & $\begin{array}{l}\text { Extremely } \\
\text { statistically } \\
\text { significant }\end{array}$ \\
\hline \multirow[t]{2}{*}{ Stool test } & $\mathbf{A}$ & 1.00 & 0.80 & 0.0 & 0.41 & 0.0 & 0.11 & 28 & 1.8708 & 0.0719 & 20 & $\begin{array}{l}\text { Not quite } \\
\text { statistically } \\
\text { significant }\end{array}$ \\
\hline & $\bar{B}$ & 1.00 & 0.13 & 0.00 & 0.35 & 0.00 & 0.09 & 28 & 9.5394 & 0.0001 & 77 & $\begin{array}{l}\text { Extremely } \\
\text { statistically } \\
\text { significant }\end{array}$ \\
\hline \multirow[t]{2}{*}{$\begin{array}{l}\text { Scotch tape } \\
\text { test }\end{array}$} & $\mathbf{A}$ & 1.00 & 0.87 & 0.00 & 0.35 & 0.00 & 0.09 & 28 & 1.4676 & 0.1534 & 14 & $\begin{array}{l}\text { Not } \\
\text { statistically } \\
\text { significant. }\end{array}$ \\
\hline & B & 1.00 & 0.20 & 0.00 & 0.41 & 0.00 & 0.11 & 28 & 7.4833 & 0.0001 & 100 & $\begin{array}{l}\text { Extremely } \\
\text { statistically } \\
\text { significant }\end{array}$ \\
\hline
\end{tabular}


ISSN: 0976-5921

Krishna Santoshi M et.a.l., A Clinical Study on the therapeutic effect of Katu taila Pichu in Pureeshaja Krimi

\section{Effect of treatment on Anidra}

Study sample shows that out of 30 patients $80 \%$ of the patients suffered from Anidra. In group B the treatment was effective by $100 \%$ in reducing symptom and was statistically significant $(\mathrm{p}<0.001)$. Where as in group A there was no marked relief and the change was not statistically significant ( $p$ $>0.001$ ).

\section{Effect of treatment on Agnimandya}

Study sample shows that out of 30 patients $93 \%$, of the patients suffered from Agni mandya. In group B the treatment was effective by $77 \%$ in reducing symptom, was statistically significant $(\mathrm{p}<0.001)$. Where as in group $\mathrm{A}$ there was no significant relief.

\section{Effect of treatment on Vaivarnya}

Of the 30 patients in the study $60 \%$, of the patients suffered from Vaivarnya. In group B the treatment was effective by $86 \%$ in reducing symptom, was statistically significant ( $p$ $<0.001$ ) by $9^{\text {th }}$ week. Where as in group A the effect was $20 \%$ and the change was not statistically significant $(\mathrm{p}>0.001)$. Vaivarnya in helminthiasis may be due to allergic response for the toxins released from the body of the Krimi. With the elimination of Krimi vaivarnyam might have reduced.

\section{Effect of treatment on Udarasoola}

Out of 30 patients in the study, $90 \%$ of the patients suffered from Udarasoola. In group B the treatment was effective by $100 \%$ in reducing symptom, was statistically significant $(p<0.001)$ by $6^{\text {th }}$ week. Where as in group A the reduction was $15 \%$ and the change was not statistically significant $(\mathrm{p}>0.001)$. The trial drug might have possibly rendered the worms immobile and terminated them later those were gradually eliminated, thereby reducing pain.

\section{Effect of treatment on Pratisyaya}

A total of $87 \%$ patients in the study suffered from Pratisyaya. In group B the treatment was effective by $93 \%$ in reducing symptom and was statistically significant $(\mathrm{p}<0.001)$ by $9^{\text {th }}$ week. Where as in group A the reduction was $37 \%$ and the change was not statistically significant $(p>0.001)$. Pratisyaya in worm infestation may be due to kapha predominance of disease. Vatakapha vitiation might have caused pratisyaya.

\section{Graph No. 1: Distribution of Symptoms}

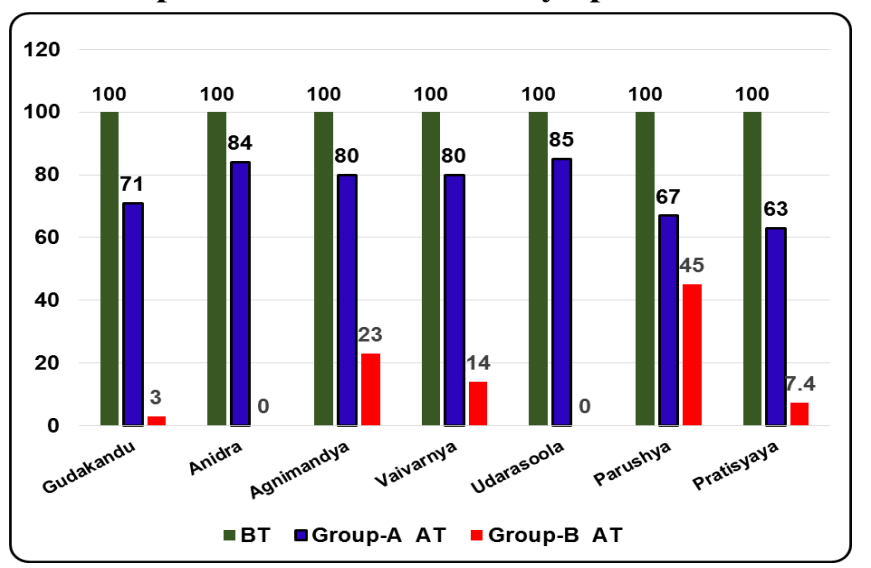

Table No. 2: Showing improvement in both groups

\begin{tabular}{|l|c|c|}
\hline \multirow{2}{*}{ Improvement } & \multicolumn{2}{|c|}{ No. of patients } \\
\cline { 2 - 3 } & Group-A & Group -B \\
\hline No Improvement & 9 & 0 \\
\hline Mild Improvement (0-25\%) & 4 & 0 \\
\hline Moderate Improvement (26-50\%) & 2 & 1 \\
\hline Good Improvement (51-75\%) & 0 & 12 \\
\hline Marked Improvement (76-100\%) & 0 & 2 \\
\hline
\end{tabular}

Graph No. 1: Showing the Improvement

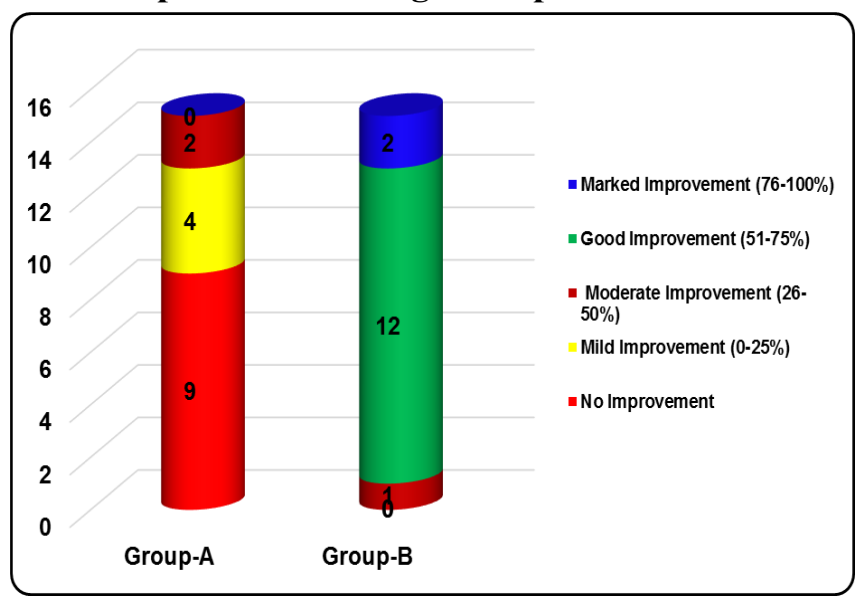

Table No. 2: Showing percentage improvement in both groups

\begin{tabular}{|l|l|l|}
\hline & Group-A & Group-B \\
\hline Overall Improvement & $9.80 \%$ & $66.97 \%$ \\
\hline
\end{tabular}

Graph No. 3: Showing percentage improvement in both groups

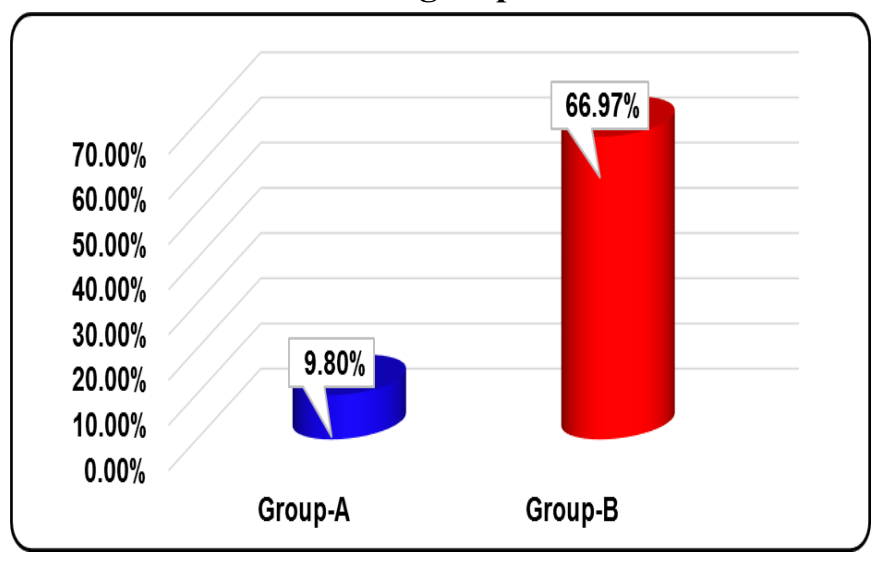

Discussion on probable mode of drug action

The present study aims at accomplishment of prakriti vighatam (4) of krimi by interfering with the life cycle of enterobious worm.

In our classics Acharyas said that drugs action depends upon their properties i.e. few drugs may act by their rasa, some by their guna and some other by their Virya or Vipaka, sometimes they may act by virtue of their Prabhava also. Due to their properties like Rasa Karma, Dosha Karma, Vyadhi Karma, they are able to cease the Samprapti of the disease. 
By going through the Samprapti of the disease of Krimiroga, it becomes evident that the Kapha Dosha plays the important role in its pathogenesis. In other words it is a Kapha predominant Vyadhi along with the involvement of Pitta and Vata. The Dushya involved in samprapti of Krimi Roga are Anna Rasa, Rasa, Rakta (in case of Raktaja Krimi) and Purisha. The Srotodushti 'Sanga' is seen here.

Unlike other helminths, gravid female Enterobius worm typically has a characteristic feature of laying eggs on perianal \& perineal region for want of oxygen and suitable environment i.e. favourable temperature \& moist condition. Eggs adhere to perianal skin because of albuminous coating \& mucoid material. This slimy material causes irritation in skin leading to itching, in turn the affected individual scratches. Scratching further may lead to dermatitis \& lesions which may exacerbate due to secondary infection. By inserting guda pichu made of Luke warm katu taila mixed with a pinch of saindhava lavana, slightly into the anus:

The desired effect of anti- itching \& wormicidal action is attained by luke warm Katu taila swab as it helps in piercing \& disintegration of double layered cell wall of the egg (outer hard chitin \& inner embryonic lipoid) by virtue of its teekshna guna making the cyst get completely destroyed, thereby interfering the continuity of the lifecycle of Enterobius worm. is the Immediate relief from perianal itching, is achieved because of hot pungent nature of drug

Katu taila is katu rasa pradhana dravya, and possesses teekshna guna.

Katu rasa is predominant of agni mahabhuta which disintegrates kapha dosha

(Kapha vilayana) which is wormicidal(5), alleviates krimi multiplying factors (i.e., kaphahara.) thus samprapti vighatana is attained.

All Lavanas have piercing or cutting nature (chedana), Saindhava lavana, best of lavanas has been used in this study to give an added effect for destroying thick shells of ova/ cyst (composed of 2 layers of external hard chitin \& inner embryonic lipoid) might be by exosmosis and subsequent dehydration.

Long contact time helps in preventing the hatching of eggs preventing retroinfection. Oil prevents oxygen transport leading to suffocation.

As no more eggs survive, thumb sucking does not cause autoinfection.

This medicated swab prevents retro and auto infection preventing further dermatitis, skin lesions \& secondary infection.

Mechanical / physical removal of swab helped in physical removal of cysts or eggs.

These symptoms are subsided as soon as the antigenic and anti-allergic reaction of body to the worms is subsided.

The study conducted proved paralytic effect of katu taila in helminthes.
Allyl isothiocyanate is an organosulphur compound present in mustard oil that has a nematocide property. Hydrolysis of allyl isothiocyanate gives allylamine. The mechanism by which AITC kills helminths and its action resembles that of polymyxin B (Source) Polymyxins have high affinity for phospholipids. They have detergent-like action on the cell membrane \& bind to phospholipids on the bacterial cell membrane of gram-negative bacteria causing membrane distortion or pseudopore formation i.e. disrupts cell membrane integrity. It leads to leakage of cellular components (ions, amino acids, etc.) \& ultimately cell death. They exhibit synergism with many other AMAs by improving their penetration into the bacterial cell as well.

\section{Discussion on follow-up}

The patients were followed at the end of $10^{\text {th }}$ week for post study follow up. None of these patients had any complaints during follow up period.

\section{Conclusion}

The present study entitled "A clinical study on the therapeutic effect of Katu taila pichu (medicated cotton swab) in Pureeshaja Krimi W.S.R to Enterobius vermicularis infestation" (Pin worm -Enterobious vermicularis)" was carried out on 30 Krimi patients divided in two groups A, B. For Group - A Patients jala pichu was given to insert into anal canal before going to bed. Group B Patients tepid Katu taila pichu along with saindhava lavana was given to insert into anal canal before going to bed. The patients were followed at the end of $3^{\text {rd }}, 6^{\text {th }}$, and $9^{\text {th }}$ week. At the end of the study the following conclusion was drawn. Krimi roga or Pinworm infestation is most commonly seen in pre-school and school going children. Maximum of $56.70 \%$ patients between 1-5years age, followed by age group 6-10 years showing 33.3\%. Parasitic infections are typically acquired at a time when the child is developing rapidly, during what are colloquially termed "the formative years". There is a danger of a cumulative effect on development in regions where children suffer from an unremitting sequence of parasitic infections.

The nidana being improper personal and environmental hygiene, living conditions in pinworm infestation. In the present study maximum $77 \%$ were found to have long nails, while $23 \%$ not having long nails. This data supports the Hand to mouth (fecal-oral route) transmission of enterobious, through long nails.

So the samprapti of krimi roga agnimandya and ama utpatti are the main cause for manifestation of the disease. This was reestablished in the present study as, $57 \%$ patients were found to have avara agni bala, $36 \%$ were of Madyama agni bala,

Gudakandu and udarasoola that were $100 \%$ and 90\% prevalent among children. The katu taila pichu given to group-B patients was highly efficacious in 
bringing the severity down 39 and $60 \%$ respectively with in first few days of management. The other symptoms also had got diminished significantly, whereas the jala pichu that was given to Group-A did not have significant improvement in the patients. Remarkable difference between group- A and GroupB. So it can be inferred that Katu taila pichu (trail drug) is efficacious.

The trial also established elimination of egg/ ova/ cyst of pinworm in subjects. These findings also establish samsamana methods as described by Acharya caraka as apakarsana, prakriti vigata, samsodana, and nidana parivarjana are effective in management of krimiroga. It may be concluded that enterobiasis was controlled by interrupting the autoinfection cycle and reducing the reservoir of infection.

From the present clinical study the trial drug was free from unwanted side effects, adverse reactions in its therapeutic dose and form in the study duration. Therefore it may be assigned safe and effective alternative for pin worm infestations.

\section{References}

1. Atharvaveda $2 / 32 / 6$

2. Burkhart CN, Burkhart CG (October 2005). "Assessment of frequency, transmission, and genitourinary complications of enterobiasis (pinworms)". International Journal of Dermatology. 44 (10):837 40. doi: 10.1111/j. 13654632.2004.02332.x. PMID 16207185.

3. Kasyapa Samhita or Vriddhajivakiya Tantra, Prof. (Km.) P.V. Tewari, Chaukhambha Viswabharati, Oriental Publishers and Distributors, Varanasi.Reprint: 2008, Chikitsa stana 15th chapterKrimi Chikitsa,5thphrase.

4. Caraka Samhita with critical exposition based on Cakrapanidatta's Ayurveda dipika by RK sharma, and Bhagwan Dash- Chowkhambha Sanskrit series office -, Varanasi-reprint-2016, Vimana stana 7/20

5. Vagbhata's Astanga Hridayam- Translated by Prof. K.R.Srikantha Murthy- Chowkhamba Krishnadas Academy, Varanasi- Edition- reprinted, 2010, sutrastana 10/17.
6. Chavali's Principles and Practice of Paediatrics in Aayurveda Dr.C.H.S. Sastry, Dr. Krishnadutt Chavali, Dr. Anita Gayatri, Dr. Viswanath Chavali, Chaukhambha Visvabharati, Varanasi, Second Revised Edition : 2015.

7. Dey T.K, Medical Parasitology-11th edition-2010New Central book agency (P) Ltd.-london.

8. Ghai Essential Paediatrics, Eighth Edition, Editors - Vinod K.Paul, Arvind Bagga, C.B.S. Publishers \& Distributors Pvt Ltd, New Delhi- 2013.

9. Harsh Mohan; Text Book of Pathology (1998); 4th edition, Jaypee Brothers Medical publishers (p) Ltd; New Delhi.

10. Nelson text book of paediatrics, 19th edition, Elsivier

11. Sharma P.V.: Dravya Guna Vigyana vol. I \& II, Choukhambha Sur Bharati Academy, Varanasi, 9th edition

12. Sharma Priyavrat; Dravya Guna Vignana; Vol.IIV, Reprint edition, 1999; Chaukhambha Bharathi Academy, Varanasi, Uttar Pradesh.

13. Vachaspatyam: Compiled by Taraknatha Tarka Vachaspati, 1962, Chaukhamba Bharati Prakashan, Varanasi.

14. Vagbhata's Astanga Samgraha-By Dr P.Srinivas Rao-Chowkhamba Krishnadas Academy-First edition-2009

15. Williams Sir Monier; A Sanskrit English Dictionary (1999): 1st edition; Motilal Banarasidas publishers Pvt. Ltd, Delhi.

16. Shin, I. S.; Masuda, H.; Naohide, K. (2004). "Bactericidal Activity of Wasabi (Wasabia japonica) against Helicobacter pylori". International Journal of Food Microbiology. 94 (3): $\quad$ 255-261. doi:10.1016/ S0168-1605(03)00297-6. PMID 15246236.

17. Nematicidal activity of allylisothiocyanate from horseradish (Armoracia rusticana) roots against Meloidogyne incognita.

18. Aissani N1, Tedeschi P, Maietti A, Brandolini V, Garau VL, Caboni P. PMID: 23627288 DOI: 10.1021/jf4008949

19. Caraka Samhita with critical exposition based on Cakrapanidatta's Ayurveda dipika by RK sharma, and Bhagwan Dash- Chowkhambha Sanskrit series office -, Varanasi-reprint-2016. 